\title{
Jackie (and Jill) Robinson in the Statehouse: Gender and Educational Attainment Influences on Office-Holding and Leadership Positions in the U.S. States
}

\author{
Jayme L. Neiman $^{1}$ \\ ${ }^{1}$ Assistant Professor, Department of Political Science, University of Northern Iowa, United States \\ Correspondence: Jayme L. Neiman, Assistant Professor, Department of Political Science, University of Northern Iowa, \\ United States.
}

Received: March 21, 2017

doi:10.11114/ijsss.v5i6.2290
Accepted: May 8, 2017 Available online: May 13,2017

URL: https://doi.org/10.11114/ijsss.v5i6.2290

\begin{abstract}
While legislative gender disparity has declined over the past few decades, gender imbalance has continued to be a stubborn fact of representative democracy in the United States. This divide persists even though females have caught up in terms of the historical educational gap. These societal shifts have been significant, however little time has been devoted to analysis of legislator education levels and none to the relationship with gender in the extant literature. This paper seeks to fill that gap, looking at the intersection through the lens of one of the prevailing theories of the expectations of female candidates and legislators.
\end{abstract}

Keywords: U.S. state legislatures, women in politics, gender and politics, Jackie and Jill Robinson, education and politics, political leadership

\section{Introduction}

While legislative gender disparity has declined over the past few decades, gender imbalance has continued to be a stubborn fact of representative democracy in the United States. Of the more than 17,000 people who served as state legislators between 2000 and 2013, less than a quarter were women (Women's Legislative Network 2013). This divide persists even though females have caught up in terms of the historical educational gap. In fact, women have outnumbered males in colleges since the 1970s (Borzelleca 2012), earn a majority of masters and doctoral degrees (Kent 2012), and nearly half of law degrees (American Bar Association Commission in Women in the Profession 2013). These societal shifts have been significant, however little time has been devoted to analysis of legislator education levels and none to the relationship with gender in the extant literature. This paper seeks to fill that gap, looking at the intersection through the lens of one of the prevailing theories of the expectations of female candidates and legislators.

Drawing from a discussion of Jackie Robinson, the first African American to play Major League Baseball and who is largely agreed to be one of the best players in the history of baseball, researchers Sarah Anzia and Christopher Berry (2011) developed a theory that they deem 'The Jackie (and Jill) Robinson Effect'. They posit that Robinson had to be better than any of his white counterparts in order to even have had the chance to play. If he had been replaceable by any white player, he would have been. Anzia and Berry posit that this principle is transferable to politics. They suggest that a 'performance premium' (p. 480) is expected of females who are running for, or holding political office. Voters and institutions are biased against women, therefore a female candidate/legislator must not simply be as good as her male counterpart - she must be better. Further, women who are considering running for office will anticipate this bias, or, falling victim to it themselves, will underestimate their own qualifications. This results in only the most highly qualified women running for and obtaining political office.

The 'Jackie (and Jill) Robinson Effect' theory is in line with much of the existing research on female candidates and elected officials. Though there is some evidence that voters tend to prefer male candidates overall (Fox and Smith 1998; Sanbonmatsu 2002; Streb, Burrell, Frederick, and Genovese 2008), and candidates with 'masculine' traits (Rosenwasser and Dean 1989; Huddy and Terkildsen 1993), more recent research shows that female candidates for office win the seat with a frequency similar to their male counterparts (Lawless 2014). This is not to say that everything is all fair and equal; there is plenty of evidence demonstrating that women continue to fight an uphill battle when it comes to running for and 
serving in office. Scholarship as of late has focused in on candidate selection/emergence. The decision of whether to run or not is affected by a variety of factors including ambition (Fox and Lawless 2011), current position (Johnson, Oppenheimer and Selin 2012); and recruitment (Fox and Lawless 2010).

Further, experimental participants tend to seek out more competence-related information about female political candidates than they do for male candidates (Ditonto, Hamilton, and Redlawsk 2013). Even when voters prefer the female candidate in a race against a male candidate, some version of social desirability leads to substantial misrepresentation of this preference to pollsters, leading to systematic underestimation of the female candidate (Stout and Kline 2011).

Potential female candidates tend to underestimate their own qualifications for officeholding (Dodson 1998; Fowler and McClure; Swers 2002). Further, Pearson and McGhee (2009) find that female congressional candidates tend to have greater prior political experience than male candidates do, indicating that women don't run unless they feel extra qualified compared to the self-assessment of male candidates.

Anzia and Berry test their theory using a measure of legislative performance-success in delivering federal program spending back to one's home district. While they do find a clear result-female legislators are more successful than their male peers in terms of bringing funding back to their home districts - I posit that there is another, simple test for the theory: legislator education levels. Very little, if any, systematic research has been done on the educational attainment of state legislators. Education levels serve as important markers for signaling competence and employability (Wittekind, Raeder, and Grote 2010; Biesta 2009), and considering what we know about the expectations of competence and experience for female candidates both internally and externally, the 'Jackie (and Jill) Robinson Effect' should produce a higher mean education level among female state legislators than male state legislators.

\section{Sample and Results}

In order to examine the education levels of female legislators I assembled a data set of the 17,211 people who have held state legislative office in the United States from 2000 to 2013 and coded each for their gender ( $0=$ Female,1=Male). Information about the legislators' education levels was then obtained from Project Vote Smart (www.votesmart.org). Educational attainment data did not exist for all of the legislators but was available for the vast majority $(15,028)$. Each legislator was coded for their level of education: 1= High School Diploma; $2=$ Some college or Associates Degree; $3=$ Bachelors or other 4-year Degree; or 4= Graduate Degree. See Table 1 for the descriptive statistics.

Prior research has indicated that legislative professionalism, or legislative capacity, may have an effect on the gender make-up of a legislature. Researchers have been divided about the effect that legislative professionalization has on the proportion of legislators that are female (Brzinski and Nye 1993; Freeman and Lyons 1992; Darcy, Welch and Clark 1987; Rosenthal 1996; Considine and Deutchman 2008; Fox and Lawless 2011), however, most find that professional legislatures tend to be more heavily male. Freeman and Lyons noted that 'the speculation in the 1960 s was that the trend toward more professionalized state legislatures would reduce the number of women in office' (Freeman and Lyons 1992). Indeed, Darcy, Welch and Clark (1987), Rosenthal (1996), and Considine and Deutchman (2008) found that women were, in fact, less represented in the more professionalized legislatures. Due to the potential influence of legislative professionalism, it is included as a control variable and in the descriptive statistics.

Table 1. Descriptive Statistics of Sample

\begin{tabular}{llllll}
\hline & $\mathrm{N}$ & Minimum & Maximum & Mean & Std. Dev. \\
\hline Gender & 17,211 & 0 (female) & 1 (male) & .7582 & .4282 \\
Education & 15,028 & 1 & 4 & 3.18 & .863 \\
Professionalism & 17,211 & 1 & 3 & 2.1977 & .7115 \\
\hline
\end{tabular}

State legislators are clearly still largely male and highly educated. Less than one quarter of the state legislators who have held office in the 14 years included in the sample are women (Table 1), even though women make up more than half of the population of the United States. State legislators also tend to have far more education than the ordinary American, holding more than a Bachelor's degree on average, while only around 30 percent of Americans hold an undergraduate college degree.

A one-way ANOVA indicates that the more professional legislatures are more educated than the citizen legislatures $(\mathrm{F}(2$, $15,025)=79.635, \mathrm{p}<.001)$. The most professional legislatures have a mean education level of $3.26(\mathrm{SD}=.812)$, compared to the middle group $(\mathrm{M}=3.23, \mathrm{SD}=.837)$ and the legislatures with the lowest professional capacity $(\mathrm{M}=3.05, \mathrm{SD}=.911)$. While all of the levels of legislative professionalism show high average education levels - considerably higher than the American average - it appears as if states with highly professionalized legislatures tend to elect, perhaps even value, representatives with higher education levels.

In line with the bulk of the previous research, the present sample demonstrates that the more professionalized legislatures also tend to be more heavily male $(\mathrm{F}(2,17,208)=6.931, \mathrm{p}=.001)$ than their less professionalized counterparts. The legislatures with the most capacity $(\mathrm{M}=.764, \mathrm{SD}=.425)$ and those in the middle $(\mathrm{M}=.769, \mathrm{SD}=.422)$ are not statistically 
different from each other, though the least professional legislatures do have more females ( $M=.743, \mathrm{SD}=.437)$.

In order to test the hypothesis that female legislators will have higher education levels than their male counterparts, an ANOVA analysis was used to compare their mean education levels. Surprisingly, and contrary to the hypothesis, this analysis does not show an educational attainment difference between male and female state legislators $(\mathrm{F}(1,15,026)$ $=.686, \mathrm{p}=.407)$. Both male $(\mathrm{M}=3.18, \mathrm{SD}=.866)$ and female $(\mathrm{M}=3.17, \mathrm{SD}=.851)$ state legislators, on average, have slightly more than a bachelor's degree. These results, unexpectedly, support the null hypothesis: female state legislators are not more educated than their male counterparts.

There also is no mean difference in the relative education levels of male and female legislators that depends on the professional capacity of the legislatures. As Table 3 demonstrates, the average education level of women and men both is lower in the least professionalized legislatures; however the differences are similar for both genders. While a generalized linear model that examined the effects of gender, legislative capacity, and the interaction of the two on education levels does show statistical significance $(\mathrm{F}(5,15,022)=31.967, \mathrm{p}<.000)$, the effect is driven solely by legislative professionalism - neither gender nor the interaction term provides a unique contribution to the model.

Table 2. Mean Education Levels by Gender and Legislative Professionalism

\begin{tabular}{lcrr}
\hline \multirow{4}{*}{ Males } & Level of Professionalism & Mean Education Level & SD \\
\cline { 2 - 5 } & 1 & 3.27 & 0.812 \\
\hline \multirow{3}{*}{ Females } & 2 & 3.23 & 2182 \\
& 3 & 3.06 & 5485 \\
& 1 & 3.25 & 0.944 \\
\hline
\end{tabular}

\section{Women in Leadership}

In the previous section the results of the data analysis indicated that female legislators do not have higher levels of educational attainment than male legislators. This was contrary to the hypothesized results, however there are some possible explanations. First, there exists a rich literature looking at the political knowledge and sophistication of the average voter. Though there is certainly variation, the clear theme is that the mass public largely lacks information about politics (Althaus 1998; Bartels 1996; Converse 1964; Delli Carpini and Keeter 1996;Zaller 1992). There may be reason to doubt whether voters are even aware of the candidates' educational attainment at all.

Second, research shows that when female candidates do run for office they are just as likely to win as their male counterparts (Fox and Lawless 2010; Seltzer et al. 1997; Smith and Fox 2001; Lawless and Pearson 2008). These findings have lead researchers to look for more institutionally-based explanations for the gender gap in elected offices. For example, when decisions about leadership are made by the members of a group, the decision is affected by the gender of the group members (Cotter et al. 2001; Paz Espinosa and Ferreira 2013). Thus perhaps it is within the leadership of state legislatures that we should be looking for educational attainment differences that are symptomatic of the 'Jackie (and Jill) Robinson Effect'.

Using the data set of the 15,028 legislators for whom educational attainment information was available, binary logistic regression analysis was used, to examine the effect of gender and education (and an interaction of the two) on obtaining a leadership position in the legislature (Table 3). The results indicate that while education does predict leadership in that those with higher levels of education are more likely to become leaders, neither gender nor the interaction of gender with education is predictive.

Table 3. Logistic Regression Analysis Predicting Leadership Positions

\begin{tabular}{llll}
\hline & $\mathrm{B}$ & Sig & $\operatorname{Exp}(\mathrm{B})$ \\
\hline Gender & .942 & .227 & 2.556 \\
Education Level & .581 & $.004^{*}$ & 1.787 \\
Gender*Education Interaction & -.162 & .459 & .850 \\
Constant & -6.138 & $.000^{*}$ & .002 \\
\hline
\end{tabular}

Further, within the 319 legislators who held leadership positions between 2000 and 2013 there were no educational attainment differences between the men $(\mathrm{M}=3.44)$ and women $(\mathrm{M}=3.51)(\mathrm{F}(1,301)=.496, \mathrm{p}=.482)$. This finding holds at each of the levels of leadership (Table 4). There is simply no evidence for an educational attainment difference between male and female legislators either as a general body or within the leadership.

Table 4. Mean Educational Attainment at Each Level of Leadership

\begin{tabular}{llllll}
\hline & Male mean & Female mean & DF & F & Sig \\
\hline Level 1 & 3.5 & 3.38 & 71,1 & .265 & .608 \\
2 & 3.39 & 3.63 & 62,1 & 1.251 & .268 \\
3 & 3.41 & 3.33 & 79,1 & .114 & .737 \\
4 & 3.67 & 3.47 & 80,1 & .742 & .392 \\
\hline
\end{tabular}




\section{Discussion}

Based on the 'Jackie (and Jill) Robinson effect theory, this paper predicted that female legislators would have higher levels of education than their male counterparts and that this effect would be more pronounced in legislatures with increased professional capacity. Instead, findings from a sample including all of the state legislators in the United States from 2000 to 2013 provide evidence that female legislators are not significantly more educated than male legislators on average; they are very much on par.

Considering these results, perhaps it is not so much that we are expecting more from women, but that in an effort to make our legislatures more experientially diverse we are just expecting different things from men and women. There is a litany of research on the differing styles men and women have in terms of campaigning and legislating. For example, female legislators have been found to be 'less confrontational, [and] more willing to reach reasoned, bipartisan compromise' (Cowan 2013). In that Anzia and Berry had found that women legislators bring more money back to their districts, perhaps this is not due to 'better' performance, but due to a more compromising, bipartisan style of legislating.

Further, we have traditionally expected that as women's presence in high positions in the so-called 'pipeline' careers (such as law and business) the proportion of women in elected positions would increase. Of course there has been an increase, but not to the extent that women have increasingly entered these fields. It is possible that women's consideration of politics is less related to these career fields. In fact, a cursory look at the Massachusetts state house reveals that while business and law are represented in the top three career fields that female representatives came from, the modal career field was non-profit work and advocacy. Considering the previous research on female legislators and increased compassion and compromise, this is an area that deserves further attention in the future as it again indicates that we may be expecting different things from our female legislators than from male legislators.

Summarily, considering the findings presented herein and the extant research on the candidacy, election, and performance of female legislators, there is reason to reexamine the Jackie (and Jill) Robinson Effect theory. There is some indication that there may not exactly be a performance premium that we are applying to our female lawmakers but rather a more nuanced differentiated expectation that defies a simple 'more' or 'less' label.

\section{References}

Althaus, S. L. (1998). Information Effects in Collective Preferences. American Political Science Review, 92(3), 545-558. https://doi.org/10.2307/2585480

American Bar Association Commission on Women in the Profession. (2013). A Current Glance at Women in the Law. Online at http://www.americanbar.org/content/dam/aba/marketing/women/current_glance_statistics_feb2013.authcheckdam. pdf

Anzia, S. F., \& Berry, C. R. (2011). The Jackie (and Jill) Robinson Effect: Why Do Congresswomen Outperform Congressmen? American Journal of Political Science, 55(3), 478-493. https://doi.org/10.1111/j.1540-5907.2011.00512.x

Bartels, L. M. (1996). Uninformed Votes: Information Effects in Presidential Elections. American Journal of Political Science, 40(1), 194-230. https://doi.org/10.2307/2111700

Biesta, G. (2009). Good Education in an Age of Measurement: On the Need to Reconnect with the Question of Purpose in Education. Education Assessment, Evaluation and Accountability, 21(1), 33-46. https://doi.org/10.1007/s11092-008-9064-9

Borzelleca, D. (2012). The Male-Female Ratio in College. Forbes. Online at http://www.forbes.com/sites/ccap/2012/02/16/the-male-female-ratio-in-college/

Brzinski, J. B., \& Nye, B. (1993). Recruitment of Women Candidates in the 1992 Congressional Election. Paper presented at the annual meeting of the American Political Science Association, Washington, D.C.

Considine, M., \& Deutchman, I. E. (1996). Instituting Gender: State Legislators in Australia and the United States. Women and Politics, 19(4), 1-19. https://doi.org/10.1300/j014v16n04_01

Converse, P. E. (1964). The Nature of Belief Systems in Mass Publics. Ideology and Discontent (David Apter, Ed.). New York Free Press.

Cotter, D. A., Hermsen, J. M., Ovadia, S., \& Vanneman, R. (2001). The Glass Ceiling Effect. Social Forces, 80(2), 655-681. https://doi.org/10.1353/sof.2001.0091

Cowan, R. (2013). Record Number of Women Sworn Into New U.S. Congress. Chicago Tribune, January 3, 2013. Retrieved from 
http://articles.chicagotribune.com/2013-01-03/news/sns-rt-us-usa-congress-womenbre9020kt-20130103_1_women -members-tammy-baldwin-record-number

Darcy, R., Welch, S., \& Clark, J. (1987). Women, Elections, and Representation. New York: Longmans.

Delli, C. M. X., \& Keeter, S. (1997). What Americans Know About Politics and why it Matters. New Haven: Yale University Press.

Ditonto, T. M., Hamilton, A. J., \& Redlawsk, D. P. (2013). Gender Stereotypes, Information Search, and Voting Behavior in Political Campaigns. Political Behavior, 35(1), 1-24.

Espinosa, M. P., \& Ferreira, E. (2013). Glass Ceilings. NP. Retrieved from http://www.webmeets.com/files/papers/IEA/2014/551/paper\%20eva-mpaz\%20jordania.pdf

Fox, R. L., \& Lawless, J. L. (2010). If Only They'd Ask: Gender, Recruitment, and Political Ambition. Journal of Politics, 72(2), 310-326. https://doi.org/10.1017/S0022381609990752

Fox, R. L., \& Lawless, J. L. (2011). Gendered Perceptions and Political Candidacies: A Central Barrier to Women's Equality in Electoral Politics. American Journal of Political Science, 55(1), 59-73. https://doi.org/10.1111/j.1540-5907.2010.00484.x

Fox, R. L., \& Lawless, J. L. (2013). Uncovering the Origins of the Gender Gap in Political Ambition. Paper presented at the annual meeting of the American Political Science Association, Chicago, IL.

Fox, R. L., \& Smith, E. R. A. N. (1998). The Role of Candidate Sex in Voter Decision-Making. Political Psychology, 19, 405-419. https://doi.org/10.1111/0162-895X.00110

Freeman, P., \& Lyons, W. (Unknown). Female Legislators: Is There a New Type of Woman in Office? In Changing Patterns in State Legislative Careers (Moncrief, G., and Thompson, J. eds.). Ann Arbor: University of Michigan Press.

Hamilton, A., Jay, J., \& Madison, J. (1937). The Federalist. New York: The Modern Library.

Huddy, L., \& Terkildsen, N. (1993). The Consequences of Gender Stereotypes for Women Candidates at Different Levels and Types of Office. Political Research Quarterly, 46(3), 503-525. https://doi.org/10.1177/106591299304600304

Jewell, M. E., \& Whicker, M. L. (1994). Legislative Leadership in the American States. Ann Arbor: University of Michigan Press.

Kent, J. (2012). Graduate Schools See Growth in Applications and Degrees, But Enroll Fewer New Students in 2011. Council of Graduate Schools. Online at http://www.cgsnet.org/graduate-schools-see-growth-applications-and-degrees-enroll-fewer-new-students-2011

Kurland, P., \& Lerner, R. (1987). The Founders of the Constitution, Vol. 1. Chicago: University of Chicago Press.

Kurtz, K., \& Erickson, B. (2013). Legislatures: All Over the Map. National Conference of State Legislature StateStats. Online at http://www.ncsl.org/Portals/1/Documents/magazine/articles/2013/SL_0113-Stats.pdf

Lawless, J. L., \& Pearson, K. (2008). The Primary Reason for Women's Underrepresentation? Reevaluating the Conventional Wisdom. Journal of Politics, 70(1), 67-82. https://doi.org/10.1017/S002238160708005X

Malhotra, N. (2008). Disentangling the Relationship Between Legislative Professionalism and Government Spending. Legislative Studies Quarterly, 33(3), 387-414. https://doi.org/10.3162/036298008785260880

Miller, J. N. (1965). Hamstrung Legislatures. National Civic Review, 54, 178-187. https://doi.org/10.1002/ncr.4100540405

National Conference of State Legislators. (2013). 'Legislator Demographics'. Online at http://www.ncsl.org/research/about-state-legislatures/legislator-demographics.aspx

North Carolina State University College of Agriculture and Life Sciences. 'General Facts about Agriculture'. Online at http://www.cals.ncsu.edu/CollegeRelations/AGRICU.htm

Pearson, K., \& McGhee, E. (2009). 'Why Women Should Win More Often than Men: Reassessing Gender Bias in U.S. House Elections.' Unpublished manuscript, University of Minnesota.

Project Vote Smart. (2016). Online at http://votesmart.org/

Rhode, D. L. (ed). (2003). The Difference 'Difference' Makes: Women and Leadership. Stanford: Stanford University Press.

Rosenwasser, S. M., \& Dean, N. G. (1989). Gender Role and Political Office. Psychology of Women Quarterly, 13(1), 
77-85. https://doi.org/10.1111/j.1471-6402.1989.tb00986.x

Sanbonmatsu, K. (2002). Gender Stereotypes and Vote Choice. American Journal of Political Science, 46(1), 20-34. https://doi.org/10.2307/3088412

Seltzer, R., Newman, J., \& Vorhees, L. M. (1997). Sex as a Political Variable: Women as Candidates and Voters in US Elections. Lynne Reinner Publishing.

Smith, E. R. A. N., \& Fox, R. L. (2001). The Electoral Fortunes of Women Candidates for Congress. Political Research Quarterly, 54, 205-221.https://doi.org/10.1177/106591290105400111

Squire, P. (2007). Measuring State Legislative Professionalism: The Squire Index Revisited. State Politics and Policy Quarterly, 7(2), 211-227. https://doi.org/10.1177/153244000700700208

Stout, C. T., \& Kline, R. (2011). I'm Not Voting for Her: Polling Discrepancies and Female Candidates. Political Behavior, 33(3), 479-503. https://doi.org/10.1007/s11109-010-9137-6

Streb, M. J., Burrell, B., Frederick, B., \& Genovese, M. A. (2008). Social Desirablity Effects and Support for a Female American President. Public Opinion Quarterly, 72(1), 76-89. https://doi.org/10.1093/poq/nfm035

United States Census Bureau. (2007). Statistics for Owners of Respondent Firms by Owner's Education Background by Gender, Ethnicity, Race, and Veteran Status for the U.S.: 2007. Online at http://factfinder2.census.gov/faces/tableservices/jsf/pages/productview.xhtml?pid=SBO_2007_00CSCBO07\&prod Type $=$ table

United States Census Bureau. (2010). Census Bureau Reports Women-Owned Firms Numbered 7.8 Million in 2007, Generated Receipts of \$1.2 Trillion. Online at http://www.census.gov/newsroom/releases/archives/business_ownership/cb10-184.html

Wittekind, A., Raeder, S., \& Grote, G. (2010). A Longitudinal Study of Determinants of Perceived Employability. Journal of Organizational Behavior, 31(4), 566-586. https://doi.org/10.1002/job.646

Women's Legislative Network of the National Conference of State Legislators. (2013). Women in State Legislatures: 2013 Legislative Session. Online at http://www.ncsl.org/legislators-staff/legislators/womens-legislative-network/women-in-state-legislatures-for-2013. aspx

Zaller, J. (1992). The Nature and Origins of Mass Opinion. Cambridge UK: Cambridge University Press. https://doi.org/10.1017/CBO9780511818691

\section{Copyrights}

Copyright for this article is retained by the author(s), with first publication rights granted to the journal.

This is an open-access article distributed under the terms and conditions of the Creative Commons Attribution license which permits unrestricted use, distribution, and reproduction in any medium, provided the original work is properly cited. 